\title{
PENGGUNAAN METODE DISKUSI UNTUK MENINGKATKAN KEMAMPUAN BERBICARA SISWA KELAS V SD NEGERI 1 BATUGANDA
}

\author{
Ahman $^{1)}$, La Rabani ${ }^{2}$. \\ ${ }^{1)}$ SDN 1 Batuganda, Kolaka Utara, Indonesia \\ ${ }^{2)}$ Jurusan PGSD, Universitas Halu Oleo, Kendari, Indonesia \\ email:ahman@yahoo.com
}

\begin{abstract}
Astrak: Penelitian ini dilaksanakan di kelas V SD Negeri 1 Batuganda pada semester ganjil Tahun Pelajaran 2016/2017 dengan Jumlah siswa 18 orang, yang terdiri dari 9 orang laki-laki dan 9 orang perempuan. Data penelitian ini diperoleh dari tes unjuk kerja untuk mengetahui peningkatan kemampuan berbicara siswa setelah penggunaan metode diskusi. Observasi bagi guru dan siswa untuk melihat kondisi pelaksanaan tindakan. Prosedur penelitian ini terdiri dari: (1) perencanaan, (2) pelaksanaan tindakan, (3) observasi dan evaluasi, dan (4) refleksi. Hasil penelitian menunjukkan peningkatan kemampuan berbicara, peningkatan aktivitas siswa dan aktivitas guru. Hal ini dapat dilihat dari meningkatnya nilai rata-rata hasil tes sebelum tindakan, Siklus I, dan siklus II. Pada siklus I ketuntasan kemampuan berbicara adalah 55,56\% atau hanya 10 siswa yang tuntas dari 18 siswa, dengan nilai rata-rata 62,96, dan pada siklus II kemampuan berbicara telah mencapai $88,89 \%$ atau sudah 16 siswa yang tuntas dari 18 siswa, dengan nilai ratarata 76,67. Disamping itu, terjadi peningkatan aktivitas guru dan siswa dalam proses pembelajaran dari siklus I ke siklus II sebesar $25 \%$.
\end{abstract}

Kata Kunci: Metode Diskusi; Kemampuan Berbicara

\section{THE USE OF DISCUSSION METHODS TO IMPROVE THE SPEAKING ABILITY OF CLASS V STUDENTS OF SD NEGERI 1 BATUGANDA}

\begin{abstract}
This research was conducted in class V SD Negeri 1 Batuganda in the odd semester of the 2016/2017 academic year with 18 students, consisting of 9 boys and 9 girls. The data of this study were obtained from performance tests to determine the increase in students' speaking skills after using the discussion method. Observations for teachers and students to see the conditions for implementing the action. This research procedure consists of: (1) planning, (2) implementing the action, (3) observation and evaluation, and (4) reflection. The results showed an increase in speaking skills, increased student activity and teacher activity. This can be seen from the increase in the average value of the test results before the action, cycle I and cycle II. In cycle I the mastery of speaking ability was $55.56 \%$ or only 10 students completed out of 18 students, with an average score of 62.96, and in cycle II the speaking ability had reached $88.89 \%$ or 16 students had completed out of 18 students, with an average score of 76.67. In addition, there was an increase in the activity of teachers and students in the learning process from cycle I to cycle II by $25 \%$.
\end{abstract}

Keywords: Discussion Method; Speaking ability 


\section{Pendahuluan}

Terdapat empat aspek kemampuan berbahasa yang menjadi output pembelajaran bahasa Indonesia adalah membaca, mendengar, berbicara dan menulis. Keterampilan berbicara merupakan salah satu aspek yang sering dipandang sebagai keterampilan yang sulit bagi siswa dan memiliki kompleksitas, karena selain harus mempertimbangkan situasi keformalan pembicaraan, juga harus mempertimbangkan pilihan kata, struktur, dan isi pembicaraan. Dengan menguasai kemampuan berbicara, peserta didik akan mampu mengekspresikan pikiran dan perasaannya secara cerdas sesuai konteks dan situasi pada saat dia sedang berbicara.

Pendidikan adalah suatu usaha sadar dan terencana untuk menciptakan suasana belajar agar peserta didik secara aktif mengembangkan potensi dirinya untuk memiliki kekuatan spiritual keagamaan, pengendalian diri, kepribadian, kecerdasan, sikap sosial dan keterampilan yang diperlukan dirinya, masyarakat, bangsa dan negara (Sisdiknas dalam Jumali, dkk, 2004:21). Proses pendidikan yang diselenggarakan secara formal di sekolah dimulai dari pendidikan formal yang paling dasar (SD) sampai perguruan tinggi (PT) tidak lepas dari kegiatan belajar yang merupakan salah satu kegiatan pokok dengan guru sebagai pemegang peranan utama.

Pendidikan sebagai kegiatan pembelajaran telah dilakukan seusia manusia itu sendiri sebagai pelaku pendidikan. Dalam pengembangan ilmu pengetahuan dan teknologi harus ditunjang oleh kemampuan pemanfaatan, pengembangan, dan penguasaan ilmu terapan dan ilmu pengetahuan dasar secara seimbang. Salah satu usaha untuk meningkatkan penguasaan pengetahuan dasar adalah dengan meningkatkan keterampilan berbahasa.

Bahasa Indonesia adalah bahasa nasional atau bahasa negara. Standar kompetensi mata pelajaran bahasa Indonsia berorientasi pada hakikat pembelajaran bahasa bahwa belajar bahasa adalah belajar berkomunikasi dan belajar sastra adalah belajar menghargai manusia dan nilai-nilai kemanusiaannya (Depdiknas, 2004:2). Pembelajaran bahasa Indonesia diarahkan untuk meningkatkan kemampuan siswa untuk berkomunikasi dalam bahasa Indonesia, baik lisan maupun tulis serta menimbulkan penghargaan terhadap hasil cipta manusia.

Secara umum mata pelajaran bahasa Indonesia bertujuan agar peserta didik mamiliki kemampuan antara lain: (1) menghargai dan bangga menggunakan bahasa Indonesia sebagai bahasa persatuan dan bahasa negara, (2) memahami bahasa Indonesia dari segi bentuk, makna, dan fungsi, serta menggunakannya dengan tepat dan kreatif untuk berbagai tujuan, keperluan, dan keadaan, (3) menggunakan bahasa Indonesia untuk meningkatkan kemampuan intelektual, serta kematangan emosional dan sosial, (4) berkomunikasi secara efektif dan efisien sesuai denga etika yang berlaku, baik secara lisan maupun tulis, (5) menikmati dan memanfaatkan karya sastra untuk memperluas wawasan, memperhalus budi pekerti, serta meningkatkan pengetahuan dan kemampuan berbahasa, (6) menghargai dan membanggakan sastra Indonesia sebagai khasanah budaya dan intelektual manusia Indonesia (Depdiknas, 2006:2).

Pendekatan pembelajaran bahasa dan sastra Indonesia adalah pendekatan komunikatif. Dalam pembelajaran pendekatan komunikatif, pembelajaran bahasa bertumpu pada pengembangan kemampuan siswa dalam menggunakan bahasa sebagai alat ungkap pesan atau makna untuk berbagai tujuan berbahasa yang meliputi aspek menyimak, berbicara, membaca, dan menulis. Keterampilan itu merupakan wujud khas perilaku manusia yang bertumpu pada kebermaknaan (Prayitno, 2006:1).

Meskipun pengembangan ilmu pengetahuan dan teknologi selalu diusahakan, namun dalam praktiknya di lapangan masih banyak guru yang menerapkan pembelajaran konvensional. Dalam pembelajaran ini, guru hanya menerangkan materi dengan metode 
ceramah, siswa mendengarkan dan mencatat hal yang dianggap penting. Akibatnya, informasi yang didapat kurang begitu melekat pada diri siswa.

Dari fenomena yang ada, maka perlu strategi belajar 'baru' yang lebih memberdayakan siswa. Belajar merupakan kegiatan aktif siswa dalam membangun makna dan pemahaman (Suwandi, 2006:3). Guru yang profesional tidak hanya menguasai sejumlah materi pembelajaran, namun penguasaan pendekatan dan metode pembelajaran yang tepat dan sesuai mutlak diperlakukan. Untuk itu perlu kiranya para guru mampu menggunakan pendekatan dan metode yang tepat agar pembelajaran menjadi aktif, inovatif, kreatif, efektif dan menyenangkan. Penggunaan metode pembelajaran secara efektif dalam proses pembelajaran akan berimplikasi terhadap peningkatan mutu hasil belajar, siswa menjadi aktif selama berlangsungnya proses pembelajaran. Dengan demikian akan berdampak terhadap peningkatan aktivitas dan hasil belajar siswa.

Salah satu metode pembelajaran yang dipandang efektif dalam mengaktifkan siswa dalam pembelajaran adalah metode diskusi kelompok. Metode ini merupakan salah satu metode pembelajaran yang dipandang efektif untuk meningkatkan kemampuan berbicara. Metode diskusi kelompok merupakan suatu proses penciptaan lingkungan pembelajaran di kelas yang memungkinkan siswa dapat bekerja sama dalam kelompok kecil dalam mengerjakan tugas. Tujuan lain dari diskusi kelompok adalah untuk mengajarkan kepada siswa keterampilan sosial atau kerja sama. Dalam belajar kelompok tidak hanya mempelajari keterampilan khusus yaitu keterampilan bekerjasama, akan tetapi juga berfungsi untuk melancarkan hubungan kerja dan tugas-tugas. Tipe pembelajaran ini menempatkan siswa dalam kelompok belajar yang heterogen beranggotakan beberapa orang siswa dan pegelompokan dapat dilakukan secara bervariasi.

Berdasarkan data hasil ulangan harian pada tahun pelajaran 2015/2016 pada siswa kelas V SD Negeri 1 Batuganda menunjukkan bahwa kemampuan berbicara siswa masih berada di bawah standar ketuntasan minimal yang ditetapkan oleh sekolah. Persentase ketuntasan klasikal hanya mencapai 38,88\% dengan rata-rata 58,68 atau 7 orang dari 18 siswa. Kesulitan yang mereka alami dalam berbicara adalah pada aspek kelancaran dan ketepatan struktur. Siswa cenderung masih dipengaruhi oleh bahasa daerah sebagai bahasa ibu dalam pergaulan sehari-hari. Sedangkan standar KKM yang telah ditetapkan oleh sekolah yaitu 65. Hal ini menunjukkan bahwa nilai siswa masih jauh berada dibawah Kriteria Ketuntasan Minimal (KKM) yang ditetapkan oleh sekolah yakni secara klasikal $\geq 80 \%$ jumlah siswa yang harusnya mencapai KKM. Sementara itu, hasil observasi empirik di lapangan juga menunjukkan fenomena yang hampir sama. Kemampuan berbicara siswa SD berada pada tingkat yang rendah; diksi (pilihan katanya) tidak sesuai dengan konteks, kalimatnya tidak efektif, struktur bahasa yang rancu, dan isi tuturan pun tidak jelas.

Penelitian yang dilakuakan Susanti 2016 Hasil penilaian pada observasi awal, dari 19 siswa, siswa yang tuntas sebanyak 8 orang, dan yang belum tuntas 11 orang, prosentase ketutasan klasikal 42,1\%. Hasil yang diperoleh pada siklus 1; dari 19 siswa, yang tuntas sebanyak 11 orang, dan yang belum tuntas 8 orang, ketutasan klasikal pada observasi awal sebesar 57,8\%. Hasil penilaian pada observasi 2, dari 19 siswa, yang tuntas sebanyak 16 orang, dan yang tidak tuntas 3 orang, perolehan ketutasan klasikal pada observasi 2 sebesar 84,2\%. Penelitian lainnnya dilakukan Uwen S. Dkk. 2015 menggunakan metode diskusi ternyata dapat meningkatkan hasil belajar siswa kelas V pada siklus I sebesar 63,75 sedangkan siklus II sebesar 72,5. Dengan peningkatan dari siklus I ke siklus II sebesar 8,75.

Oleh karena itu salah satu upayah untuk meningkatkan kemampuan berbicara bagi siswa kelas V SD Negeri 1 Batuganda adalah penerapan metode diskusi, karena metode diskusi merupakan salah satu metode yang digunakan untuk menjadikan siswa lebih aktif dalam proses pembelajaran. 
Berdasarkan uraian di atas, penulis ingin menindaklanjuti dengan mengadakan penelitian tentang "Penggunaan Metode Diskusi kelompok untuk Meningkatkan Kemampuan Berbicara Siswa Kelas V SD Negeri 1 Batuganda".

Masalah dalam penelitian ini adalah: Apakah penggunaan metode diskusi dapat meningkatkan aktivitas mengajar guru kelas V SD Negeri 1 Batuganda? 2) Apakah penggunaan metode diskusi dapat meningkatkan aktivitas belajar siswa kelas V SD Negeri 1 Batuganda? 3) Apakah penggunaan metode diskusi dapat meningkatkan kemampuan berbicara siswa kelas V SD Negeri 1 Batuganda? Tujuan penelitian ini adalah Untuk meningkatkan aktivitas mengajar guru kelas V SD Negeri 1 Batuganda melalui penggunaan metode diskusi. 2) Untuk meningkatkan aktivitas belajar siswa kelas V SD Negeri 1 Batuganda melalui penggunaan metode diskusi. 3) Untuk meningkatkan kemampuan berbicara siswa kelas V SD Negeri 1 Batuganda melalui penggunaan metode diskusi. Penelitian ini diharapkan dapat memberikan manfaat bagi guru, siswa, sekolah dan penelitian lainnya.

\section{Metode}

Jenis penelitian adalah penelitian tindakan kelas (PTK. dilaksanakan di Kelas V SD Negeri 1 Batuganda Kolaka Utara semester ganjil tahun pelajaran 2016/2017 dengan subyek dalam penelitian ini adalah siswa kelas V SD Negeri 1 Batuganda Kabupaten Kolaka Utara yang mengikuti mata pelajaran matematika dengan materi pokok operasi hitung campuran bilangan bulat tahun ajaran 2016/2017 sebanyak 18. Penelitian tindakan kelas ini dilaksanakan dalam dua siklus yang terdiri dari empat tahapan yaitu perencanaan, pelaksanaan tindakan, observasi dan evaluasi serta refleksi Jenis data dalam penelitian ini adalah data kualitatif dan kuantitatif. Data kualitatif berupa kegiatan proses pembelajaran aktivitas belajar siswa dan aktivitas guru. Data kuantitatif berupa nilai hasil belajar siswa. Sumber data dalam penelitian ini adalah guru dan siswa Kelas V SD Negeri 1 Batuganda Kolaka Utara

Data kualitatif akan dianalisis secara deskriptif kualitatif berdasarkan observasi, sedangkan data kuantitatif dianalisis secara kuantitatif menggunakan rumus:

$\%$ Keterlaksanaan $=\frac{\text { Skorperolehan }}{\text { skorideal }} \times 100 \%$

(Nasution. 2003:29)

Data hasil belajar siswa dianalisis dengan menggunakan rumus:

Rata-rata $=\frac{\text { JawabanBenar jumlah nilai yang diperoleh siswa }}{\text { jumlah seluruh siswaTotalskor }} \times 100$

(Rakhmat,2003:153)

Menentukan persentase ketuntasan belajar secara klasikal menggunakan rumus:

$\%$ TuntasKlasikal $=\frac{\sum T B I}{N} x 100 \quad$ (Nasution, 2008: 6.11)

Indikator keberhasilan dalam penelitian ini terdiri dari:

1. Indikator tentang keterlaksanaan skenario pembelajaran.

Skenario pembelajaran dikatakan terlaksana dengan baik apabila minimal $80 \%$ skenario pembelajaran terlaksana.

2. Indikator peningkatan kemampuan berbicara siswa.

Hasil belajar Bahasa Indonesia siswa dikatakan tuntas apabila minimal 80\% siswa telah memperoleh nilai $\geq 65$ sesuai dengan Kriteria Ketuntasan Minimal (KKM) yang ditetapkan sekolah. 


\section{Hasil}

1. Hasil Belajar Siswa

Pada setiap akhir siklus dilakukan tes untuk mengukur hasil belajar siswa, berikut ini adalah grafik ketuntasan siswa pada setiap siklus:

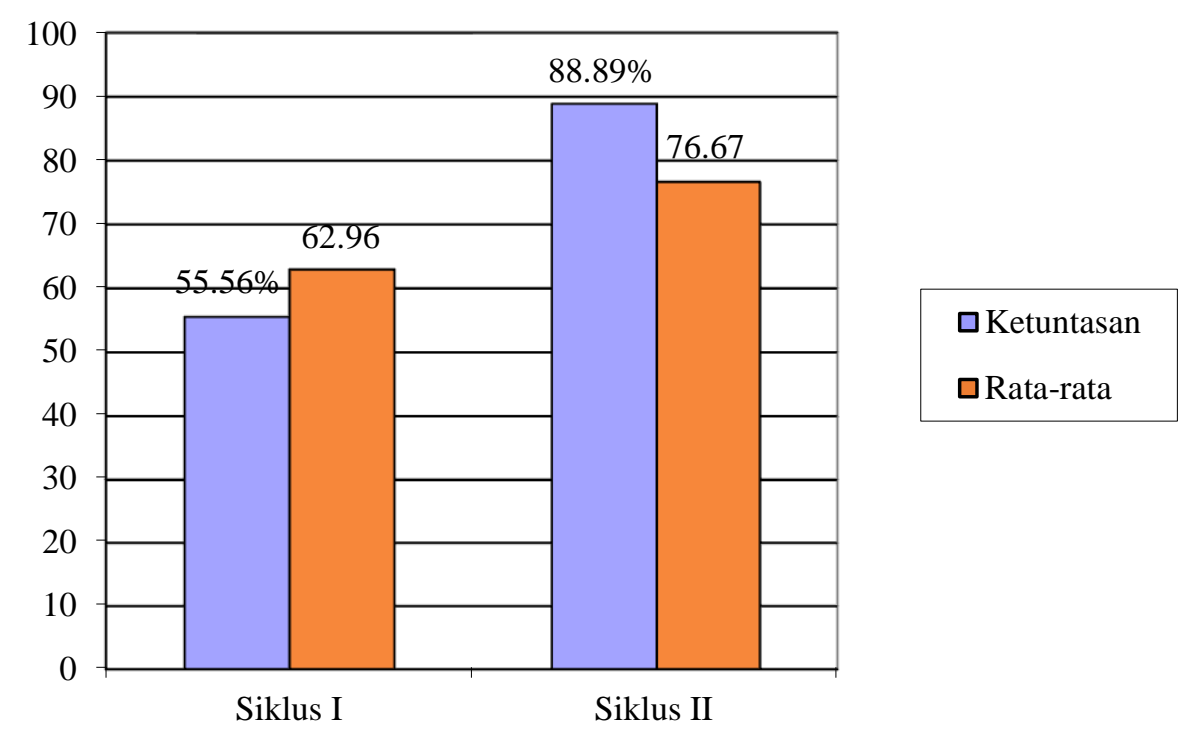

Gambar 1. Grafik Hasil Belajar Siswa Setiap Siklus

\section{Aktivitas Guru}

Selain dilaukan tes pada setiap siklus dalam proses pembelajaran juga dilakukan pengamatan terhadap aktivitas guru. Aktivitas guru diamati dengan menggunakan lembar observasi. Berikut ini grafik hasil pengamatan aktivitas guru pada setiap siklus:

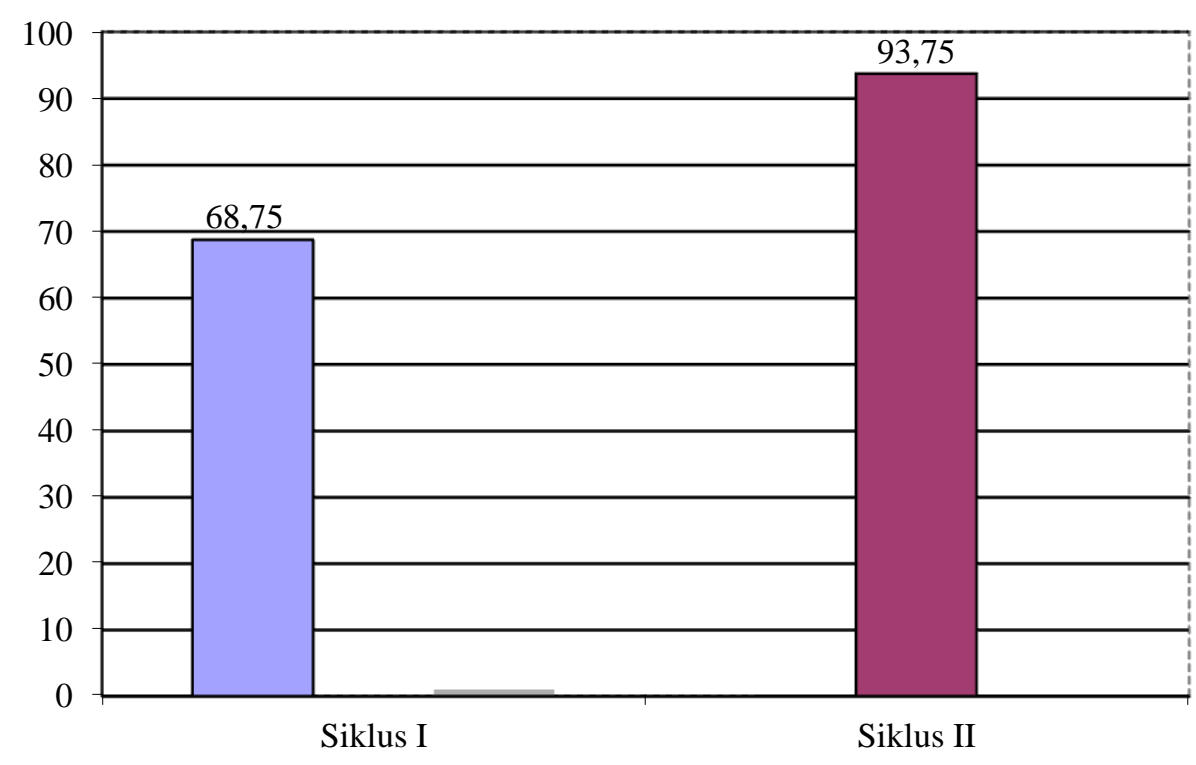

\section{Gambar 2. Grafik Aktivitas Guru Siklus I dan Siklus II}

\section{Aktivitas Siswa}

Selama proses pembelajaran selain aktivitas guru aktivitas siswa juga diamati. Berikut adalah hasil pengamatan terhadap aktivitas siswa selama mengikuti proses pembelajaran: 


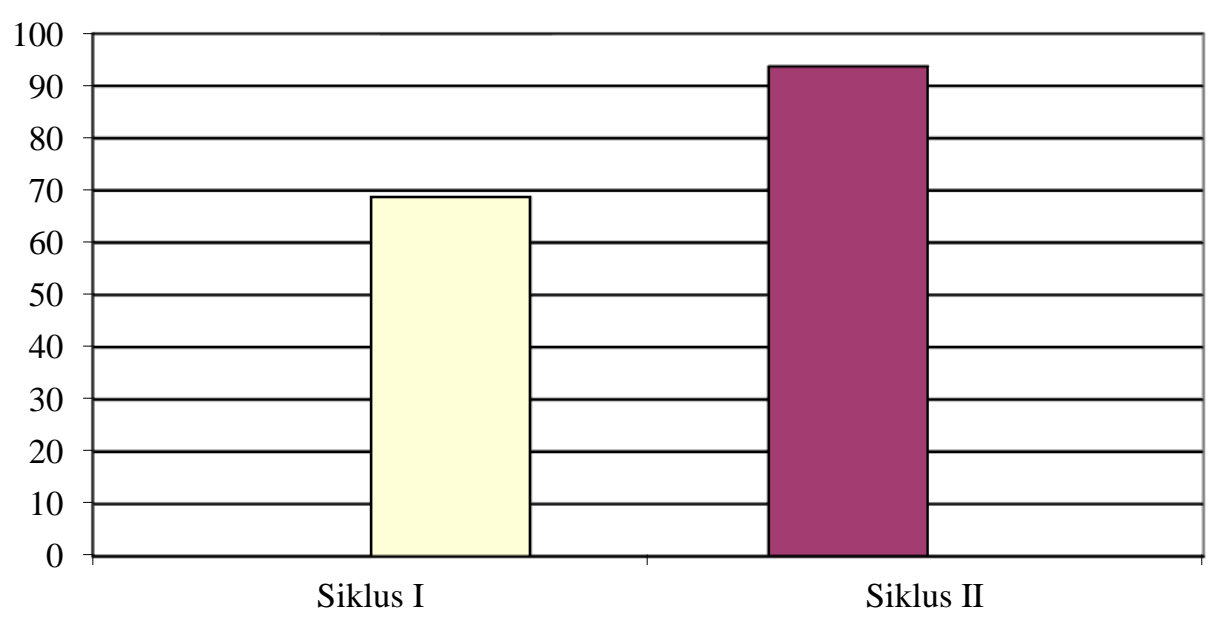

Gambar 3. Grafik Aktivitas Siswa Siklus I dan Siklus II

\section{Pembahasan}

\section{Aktivitas Guru}

Persentase aktivitas guru dalam pembelajaran mengalami peningkatan dari siklus I ke siklus II yakni persentase aktivitas guru siklus I sebesar $68,75 \%$ sedangkan pada siklus II sebesar 93,75\%. persentase aktivitas guru siklus I sebesar $68,75 \%$ menjadi $93,75 \%$ pada siklus II dengan peningkatan sebesar $25 \%$.

\section{Aktivitas Siswa}

Persentase aktivitas siswa dalam pembelajaran mengalami peningkatan dari siklus I ke siklus II. Hal ini disebabkan karena siswa benar-benar mengikuti proses pembelajaran dengan tekun. persentase aktivitas siswa siklus I sebesar 68,75\% meningkat menjadi 93,75\% pada siklus II dengan peningkatan sebesar dengan peningkatan sebesar $25 \%$.

\section{Hasil Belajar Siswa}

Hasil belajar siswa pada siklus I menunjukkan bahwa siswa yang berada pada kategori tuntas sebanyak 10 orang dari 18 orang siswa atau sebesar 55,56\% dan siswa yang berada pada kategori tidak tuntas sebanyak 8 orang atau sebesar $44,44 \%$, sedangkan pada siklus II, siswa yang berada pada kategori tuntas sebanyak 16 atau sebesar 88,89\% dan siswa yang berada pada kategori tidak tuntas sebanyak 2 orang atau sebesar 11,11 . ketuntasan hasil belajar siswa meningkat dari siklus I $(55,56 \%)$ meningkat pada siklus II $(88,89 \%)$ dengan peningkatan sebesar $33,33 \%$. Demikian juga rata-rata hasil belajar siswa meningkat dari siklus I $(62,96)$ ke siklus II $(76,67)$ dengan peningkatan sebesar 13,71.

Hasil penelitian ini mengindikasikan bahwa metode pembelajaran diskusi efektif dalam meningkatkan kemampuan berbicara siswa kelas V SD Negeri 1 Batuganda. Hal ini ditunjukkan pada pelaksanaan tindakan sebanyak dua siklus pembelajaran, dimana pada siklus II, target ketuntasan belajar telah tercapai.

Penelitian ini melihat dua hal, yakni proses pelaksanaan pembelajaran berbicara dengan menggunakan metode diskusi kelompok dan menyelidiki peningkatan hasil belajar siswa terhadap materi pembelajaran.

Aktivitas guru dalam melaksanakan metode diskusi kelompok pada pembelajaran siklus I belum maksimal. Dari 8 aspek yang diamati sebagai indikator pengamatan aktivitas guru, rata-rata kemampuan guru adalah $68,75 \%$ yang telah guru lakukan dengan baik sesuai dengan skenario pembelajaran yang telah dirancang. Ini berarti bahwa masih ada kelemahan- 
kelemahan yang dilakukan guru pada pembelajaran siklus I. Kelemahan-kelemahan yang ditemukan adalah dalam pembagian kelompok, guru tidak menunjuk ketua kelompok, guru tidak mengawasi jalannya diskusi kelompok serta guru tidak menyimpulkan hasil diskusi.

Faktor lain yang menjadi objek pengamatan dalam proses pembelajaran dengan metode diskusi kelompok adalah siswa. Data menunjukkan bahwa proses pembelajaran belum mengarah pada kegiatan siswa, akan tetapi kegiatan pembelajaran masih berpusat pada guru. Kelemahan lain yang diamati adalah siswa dalam kerja kelompok belum dapat berdiskusi dengan sempurna. Siswa masih belum memiliki rasa percaya diri dengan apa yang dibuatnya, siswa masih malu dan ragu untuk mengeluarkan pendapatnya. Kelemahan lain adalah kerjasama tim belum tampak, dominasi perseorangan atau satu kelompok dan memaksakan pendapat dalam kelompok belajar masih terjadi. Sehingga presentasi yang dihasilkan tidak utuh karena merupakan pemikiran satu orang siswa. Dalam kelompok belajar belum semua siswa berpartisipasi untuk mengemukakan pendapatnya sehingga pertanyaan-pertanyaan yang dibuat dalam LKS lambat diselesaikan. Akibatnya, alokasi waktu yang disediakan untuk mempresentasikan hasil kerja kelompok dan umpan balik dalam memberikan tanggapan belum berlangsung maksimal atau menjadi sangat singkat. Disamping itu, tak seorang pun dari siswa yang mengajukan pertanyaan ataupun menjawab pertanyaan yang diajukan oleh teman-temannya, sehingga pembelajaran yang terjadi pada siklus I tampak kaku dan pasif.

Analisis hasil belajar siswa terhadap materi yang diajarkan pada siklus I juga belum mencapai standar ketuntasan belajar, yakni rata-rata pencapaian siswa adalah 62,96 dengan jumlah siswa yang mengalami ketuntasan belajar sebanyak 10 orang dari 18 siswa atau sebesar 55,56\%. Hal ini disebabkan karena penerapan metode diskusi kelompok dalam pembelajaran bahasa Indonesia khususnya keterampilan berbicara belum terlaksana dengan baik.

Pada pelaksanaan pembelajaran siklus II, kemampuan guru dalam menerapkan metode diskusi kelompok pada pembelajaran berbicara sudah terlaksana dengan baik. Pada pembelajaran siklus II, tampak bahwa secara umum kemampuan guru dalam melaksanakan skenario pembelajaran diskusi kelompok pada pertemuan pertama sebesar $87,5 \%$ sedangkan pada pertemuan kedua sudah mencapai $100 \%$. Demikian pula halnya persentase aktivitas siswa mengalami peningkatan yakni pertemuan pertama sebesar $87,5 \%$ menjadi $100 \%$ pada pertemuan kedua. Hal ini disebabkan pada siklus II kemampuan guru dalam menerapkan metode diskusi kelompok terjadi peningkatan yang signifikan.

Data hasil evaluasi belajar siswa menunjukkan bahwa pada siklus II terjadi peningkatan hasil belajar yakni rata-rata ketuntasan belajar $88,89 \%$ dengan nilai rata-rata hasil belajar siswa 76,67, sehingga dengan demikian penelitian dihentikan sampai pada siklus II karena skenario pembelajaran yang telah ditetapkan telah terlaksana dengan baik.

\section{Simpulan}

1. melalui metode diskusi dapat meningkatkan kemampuan berbicara dalam menanggapi suatu peristiwa siswa kelas V SD Negeri 1 Batuganda. Hal tersebut dapat dilihat dari meningkatnya nilai rata-rata hasil tes sebelum tindakan, Siklus I, dan siklus II.

2. melalui metode diskusi dapat meningkatkan kemampuan berbicara dalam menanggapi suatu peristiwa di SD Negeri 1 Batuganda. Pada siklus I ketuntasan kemampuan berbicara dalam menanggapi suatu peristiwa adalah 55.56\%, dan pada siklus II kemampuan berbicara dalam menanggapi suatu peristiwa telah mencapai $88.89 \%$. 


\section{Referensi}

Depdiknas. 2004. Pedoman Pengembangan Silabus Kurikulum. 2004. Jakarta: Depdiknas.

Depdiknas. 2006. Panduan pengembangan Silabus dan Rencana Pelaksanaan Pembelajaran Kurikulum Satuan Tingkat Pendidikan (KTSP) di Sekolah Dasar.

Jumli. dkk. 2004. Landasan Pendidikan. Surakarta: MUP. Kertapati

Nasution. 2003. Metode Penelitian Naturalistik Kualitatif. Bandung: Transito.

2008. Berbagai Pendekatan dalam Proses Belajar \& Mengajar. Cetakan keduabelas. Jakarta:Bumi Aksara.

Uwen, S. dkk. Peningkatan Kemampuan Berbicara Menggunakan Metode Diskusi pada Pembelajaran Bahasa Indonesia di SD. Jurnal Pendidikan dan Pembelajaran $\begin{array}{lllll}\text { Khatulistiwa } & \text { Vol. } & 4 & \text { No. } & 6\end{array}$ https://jurnal.untan.ac.id/index.php/jpdpb/article/view/10426

Rakhmat, J. 2003. Metode Penelitian Komunikasi. Bandung: PT. Remaja Rosdakarya.

Prayitno. 2006. Motivasi Dalam Belajar. Jakarta: 2LPTK.

Susanti. 2016. Penerapan Metode Diskusi dalam Meningkatkan Kemampuan Berbicara Siswa Kelas IV SDN Ogogili. Jurnal Kreatif Tadulako Vol. 4 No. 8 https://www.neliti.com/id/publications/108751/penerapan-metode-diskusi-dalammeningkatkan-kemampuan-berbicara-siswa-kelas-iv-s

Suwandi. 2006. Semantik Pengantar Kajian Makna. Yogyakarta: Media Perkasa. 